mali nielen štastnú ruku pri výbere editovanej pamiatky, ale svojou úctyhodnou prácou a dôslednostou, kompetenciou a erudíciou pripravili pramenno-kritické vydanie, ktoré zodpovedá vysokým štandardom vedeckých edícií. Svojím záslužným muzikologickým činom obohatili pomerne málo zastúpenú oblast' hudobnej ikonografie a vedeckej dokumentácie. Precízne formulované mu- zikologické komentáre či hudobné profily $\mathrm{k}$ editovaným reprodukciám podobizní $\mathrm{z}$ fotoalbumu sú zároveň fascinujúcim čítaním $\mathrm{k}$ hudobným mikrodejinám, dávajúc podnet na úvahy, do akej miery môžu nové poznatky ovplyvnit postupné utváranie inovovaného obrazu hudobných dejín,

Jana Lengová

\title{
Deníky Ludevíta a Marty Procházkových (1868-1888) / Die Tagebücher von Ludevít und Marta Procházka (1868-1888)
}

K vydání připravili Jana VOJTĚŠKOVÁ, Jiří K. KROUPA. Praha : Národní muzeum \& KLP - Koniasch Latin Press, 2018. LX + 186 stran. ISBN 978-80-7036-579-3 (NM), ISBN 978-80-87773-61-1 (KLP)

V nedávnej dobe editori Jana Vojtěšková a Jiří K. Kroupa predložili odbornej aj širšej kultúrnej verejnosti d’alšiu spoločnú publikáciu Deníky Ludevita a Marty Procházkových (1868-1888), ktorá tematicky úzko súvisí s predchádzajúcimi dvoma kritickými edíciami prameňov a týka sa významnej osobnosti pražského hudobného života tretej tretiny 19. storočia Ludevíta Procházku a jeho manželky speváčky Marty Procházkovej. Píšeme o nich vyššie. Možno povedat', že všetky tri publikácie vytvárajú svojím predmetom bádania a editorským prístupom trojzväzkový, vzájomne sa doplňujúci komplet. Publikáciu vydalo Národní muzeum - České muzeum hudby v Prahe a pražské nakladatel'stvo KLP - Koniasch Latin Press s podporou Ministerstva kultúry ČR v rámci inštitucionálneho financovania koncepčného rozvoja výskumnej organizácie Národní muzeum. Vkusný výtvarný dizajn publikácie zachováva síce formát predchádzajúcich dvoch, avšak tentoraz namiesto dobovej úpravy preferuje moderné riešenie.

Pre hudobného historika je nielen potešujúce, ale aj vel'kou výzvou mat $\mathrm{k}$ dispozícii pramene toho typu, ako boli editované v troch spomínaných publikáciách. Je preto pochopi-

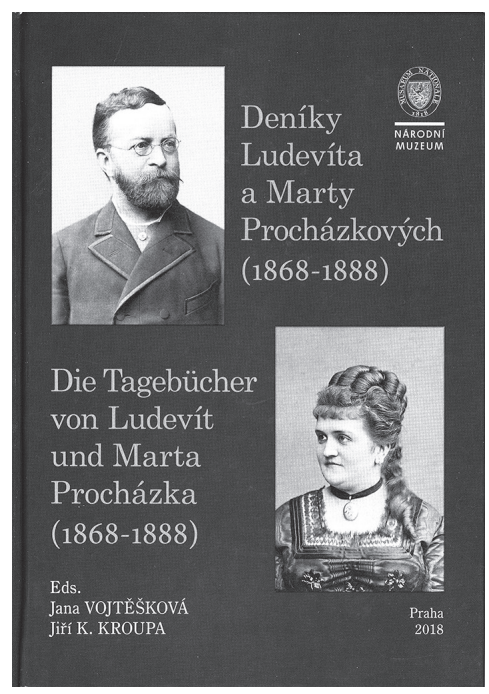

telné - a napokon to vidiet aj na výsledku -, že editori pristupovali k editorskej práci s maximálnym ludským aj muzikologickým zanietením a snahou prezentovat pramene ideálne na najvyššej vedeckej úrovni. V porovnaní s predchádzajúcimi dvoma publikáciami je prezentovaná pramenná edícia vydaná na kvalitnom, ale nie kriedovom papieri, čo zodpovedá štandardom textových publikácií. $\mathrm{Na}$ 
kriedovom papieri je vytlačená iba obrazová príloha, začlenená ako vložka medzi strany 148 - 149. Publikácia, členená koncepčne podobne ako predchádzajúce dve edície na dve časti, si zachováva tiež bilingválny charakter, avšak tentoraz vychádza v českej a nemeckej mutácii vzhladom na editované pramene, písané aj v origináli sčasti v jednom alebo druhom $\mathrm{z}$ dvoch spomínaných jazykov.

V prvej časti editori načrtávajú najmä hudobnokultúrny prínos Ludevíta Procházku, kedže koncízny biografický profil bol prezentovaný už v prvej publikácii z roku 2013. Poukazujú na jeho aktivity neuveritelného rozsahu, čo zahrnovalo jeho pôsobenie klaviristu, dirigenta, skladatela, hudobného kritika, organizátora koncertov, editora a pedagóga. Klúčová je veta: „Bez Procházkova působení by se česká moderní hudba Smetanova a jeho současníků prosazovala mnohem obtížněji“ (s. ix). Podobne aj biografický profil Marty Procházkovej bol už spracovaný v prvej publikácii, v recenzovanej práci sa detailnejší pohlad na jej spevácku kariéru sústreduje najmä na jej vystúpenia v Prahe a vo Viedni a na angažmán opernej speváčky v Hamburgu, Dráždanoch a opät v Hamburgu, ako aj jej koncertný, resp. operný repertoár.

Záznamy v editovaných denníkoch neboli písané pravidelne ani systematicky. Napriek tomu poskytujú dôležité údaje $\mathrm{k}$ poznaniu života a pôsobenia oboch manželov Ludevíta a Marty Procházkovcov tak po ludskej, hudobnej, kultúrno-umeleckej, ako aj spoločenskej stránke. Prinášajú tiež dôležitý korektív niektorých zaužívaných skutočností. Editori okrem iného upozornili napríklad na Procházkovo krstné meno, ktoré sa v staršej muzikologickej a encyklopedickej literatúre zvyklo uvádzat ako Jan Ludevít a v tejto forme ho rešpektuje aj prvá procházkovská publikácia. V matričných záznamoch narodených bol Procházka zapísaný latinsky ako „Ludovicus Joannes“, teda česky „Ludvík Jan“. Na základe toho editori dedukujú, že často používal slovenskú formu mena „Ludovít", respektíve vzhladom na svoju slovanofilskú orientáciu slovanský variant „Ludevít“ (s. xi). K tomu by som dodala, že toto krstné meno malo $\mathrm{v}$ dejinách slovenského jazyka svoje vývojové fázy: v štúrovskej dobe to bol starší tvar "Ludevít“, neskôr paralelne varianty „Ludevít“ aj „Ludovít“, posledný tvar „Ludovít" sa definitívne ustálil až v modernej slovenčine.

Základom pramenno-kritického vydania je Procházkov osobný denník z rokov 1868 - 1883, ktorý je doplnený a rozšírený o dalšie tri pramene - zápisník Marty Procházkovej a dva menšie zápisníčky Ludevíta Procházku, čím sa časový horizont denníka rozšíril na roky 1868 - 1888, počínajúc zápismi súvisiacimi s jeho sobášom až po jeho predčasnú smrt. Do vydania nie je zahrnutý pamätník Marty Procházkovej vztahujúci sa najmä na hamburský a dráždanský pobyt Procházkovcov, avšak editori dôležité poznatky z neho $\mathrm{k}$ spoločenským stykom manželov podali prehladným spôsobom $\mathrm{v}$ prvej časti publikácie, vrátane tabulky osobností zapísaných $\mathrm{v}$ tomto pamätníku (s. xx - xxii). Do edície sú zahrnuté ešte dva d’alšie pozoruhodné pramene typu oral history, ktoré napísala blízka príbuzná oboch manželov Milka Procházková-Preissová (1899 - 1981): Z rodinných vzpomínek a Co vím o Dru. Ludevitu Procházkovi a o svém dédovi varhaníku Josefu Procházkovi z Klatov (s. 113 - 146). V jednom prípade ide o typ memoárovej literatúry, v druhom o pútavo napísaný popularizujúci biografický náčrt Ludevíta Procházku a jeho otca Josefa Procházku s opisom mnohých zaujímavých udalostí týkajúcich sa rodinného aj súvekého kultúrno-spoločenského života. Prvé štyri pramene sú uložené v Národním muzeu - Českém muzeu hudby - Muzeu Bedřicha Smetany v Prahe, posledné dva v Národním muzeu - Českém muzeu hudby.

Charakter prameňov v predchádzajúcich dvoch kritických edíciách rozkrýva skôr relačný aspekt pôsobenia Ludevíta Procházku z hladiska českej hudobnej kultúry a stredoeurópskych kontextov. Približuje komunikačné procesy, osobné aj písomné väzby a kontakty, ktoré vo väčšej či menšej miere ovplyvnili jeho činnost' v oblasti hudobnej kultúry. V tretej edícii je centrom editovaných prameňov samotná osobnost' Ludevíta Procházku ako pôvodcu písomných prameňov, ktorý prostredníctvom stručných aj ob- 
sažnejších autentických záznamov v denníku a dvoch zápisníčkoch „odhaluje“ intímnu ludskú zložku svojej osobnosti a výstižnými postrehmi sa vyjadruje k svojim hudobným aktivitám a k speváckym aktivitám manželky Marty. Pramene sú písané formou, ktorá vylučuje kategóriu denníkov typu sebaprezentácie. Boli zaiste písané s vedomým či nevedomým úmyslom fixovania pamätovej stopy ako opory v priebehu plynutia času. Hypoteticky denník a zápisníčky mohli byt vedené myšlienkou napísat v neskoršom veku nejaký spomienkový spis či memoáre, literárny žáner, relatívne rozšírený v 19. storočí aj medzi hudobníkmi.

Koncepcia editorov reflektuje charakter prameňov a opätovne premyslene a dôsledne rieši ich editovanie. Kedže pod názvom $D e$ níky Ludevíta a Marty Procházkových (1868 - 1888) (s. 1 - 100) sú v chronologickej postupnosti zahrnuté všetky štyri vyššie spomínané pramene (denník a dva zápisníčky Ludevíta Procházku, ako aj zápisník Marty Procházkovej), otázku odlíšenia pridaných troch prameňov editori vyriešili graficko-farebnou úpravou, vrátane skratky príslušného prameňa. Snahou editorov bolo, ako sa píše v „manuáli“ pre používatelov knihy, „konfrontovat a ověrit všechny zapsané události a reálie $\mathrm{v}$ dalších dochovaných historických pramenech a literatuře (matriky, adresáře, seznamy obyvatelstva, programy a divadelní cedule, dobový tisk, korespondence, memoáry, sekundární literatura atd.), což se odrazilo v poměrně obsáhlých a detailních podčarových poznámkách“ (s. xxix). Tento náročný ciel’ editori v plnej miere vd’aka precíznej heuristickej, archívnej a filologickej práci splnili. Procházkove zápisy sú čo do rozsahu rôzne, niekedy velmi krátke či strohé, inokedy obsažnejšie, opisné a komentujúce. V rozsiahlom a faktograficky hutnom poznámkovom aparáte pod čiarou sa tak doplňujú, vysvetlujú, či komentujú v editovaných prameňoch zaznamenané skutočnosti, prípadne sa korigujú nepresné údaje. Dôsledný komparatívny prístup prináša aj d’alšie benefity: pôvodný zápis je vnímaný v kontextuálnom rozmere s komplexnejším videním skutočností a s novou informačnou hodnotou.

Za edíciu denníkov editori zaradili ešte dva dodatky Supplementa (s. 101 - 112), a síce zoznam operného repertoáru Marty Procházkovej (37 postáv) a výber koncertných programov z rokov 1872 - 1878, súvisiacich s umeleckou činnostou manželov Procházkovcov a dôležitých v kontexte skúmanej problematiky. Edíciu uzatvárajú dve vyššie spomínané literárne črty Milky Procházkovej-Preissovej (s. 113 - 140). Tieto dva pramene sú chápané v zmysle prameňov literárneho žánru. To znamená, že sú citlivo upravené do modernej češtiny, avšak s bohatými doplnkami a komentármi v poznámkovom aparáte.

Predkladaná publikácia skúsených editorov Jany Vojtěškovej a Jiřího K. Kroupu - podobne ako predchádzajúce dve vydania - vzbudzuje rešpekt. Detailne premyslená koncepcia, filologická, pramenná a archívna práca sú v dokonalom súlade. Editované pramene aj rozsiahle doplňujúce dáta a vysvetlenia, komentujúce $\mathrm{v}$ poznámkach pod čiarou údaje k menám a udalostiam, spomínaným v editovanom prameni, predkladajú bohaté penzum nových poznatkov. Navyše namiesto punktuálne prezentovaných dát editori dávajú prednosti ich uvádzaniu do súvislostí. Ak chápeme pramene ako médium poznávacieho procesu, recenzovaným trom procházkovským kritickým edíciám treba priznat dvojakú zásluhu. Sú zdrojom základného poznania, ktoré sa opiera o fakty, verifikované a verifikovatelné vd’aka kompetentnej a dôslednej práci editorov. Prinášajú tiež množstvo nových poznatkov, vrátane poznatkov z komentujúcich poznámok pod čiarou, a tým aj podnetov, ktoré naznačujú možnosti d’alších tematických oblastí výskumu. Všetky tri edície nadväzujú svojím spracovaním a svojou vysokou vedeckou úrovňou na znamenité tradície českej muzikológie.

Jana Lengová 